\title{
Transposition
}

Musique et Sciences Sociales

Hors-série 2 | 2020

Sound, Music and Violence

\section{Guitars Give Way to Guns: A Commentary on an Interview with Jean-Marc Rouillan}

Les guitares laissent place aux fusils : commentaire d'un entretien avec Jean-

Marc Rouillan

Matthew Worley

\section{OpenEdition}

\section{Journals}

Electronic version

URL: http://journals.openedition.org/transposition/4284

DOI: 10.4000/transposition.4284

ISSN: $2110-6134$

Publisher

CRAL - Centre de recherche sur les arts et le langage

Electronic reference

Matthew Worley, « Guitars Give Way to Guns: A Commentary on an Interview with Jean-Marc Rouillan », Transposition [Online], Hors-série 2 | 2020, Online since 15 March 2020, connection on 16 April 2020. URL : http://journals.openedition.org/transposition/4284 ; DOI : https://doi.org/10.4000/ transposition.4284

This text was automatically generated on 16 April 2020

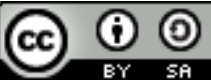

La revue Transposition est mise à disposition selon les termes de la Licence Creative Commons Attribution - Partage dans les Mêmes Conditions 4.0 International. 


\section{Guitars Give Way to Guns: A Commentary on an Interview with Jean-Marc Rouillan}

Les guitares laissent place aux fusils : commentaire d'un entretien avec JeanMarc Rouillan

Matthew Worley

\section{EDITOR'S NOTE}

The following is a commentary on: VELASCO-PUFLEAU Luis, "From Music to Armed Struggle, from 1968 to Action Directe: An Interview with Jean-Marc Rouillan", Transposition, no. Hors-série 2, 2020, https://journals.openedition.org/transposition/ 3780. DOI : https://doi.org/10.4000/transposition.3780

1 The life of Jean-Marc Rouillan brings into sharp relief the connections and overlaps between pop music, youth culture and politics that helped define the late twentieth century. As the interview reveals, music - and rock music especially - served as a segue from teenage agitation to political provocation. Guitars gave way to guns. Shaking some action transformed into Action directe. Romanticism became rebellion; a revolution of the senses fed into a revolution on the streets until clang clang went the jail guitar doors.

2 In recounting his life's trajectory to Luis Velasco-Pufleau's probing questions, Rouillan taps into much that resonated at the time and continues to resonate for scholars and politicos today. Certainly, in the late twentieth century, a correlation between music, violence and politics became clear, as rock'n'roll's tearing of the cultural fabric allowed for flesh, frustrations and freedoms to fall free. From the 1950s, creativity begat personal liberation, confronting and overturning tired expectations and social restraints. Political commitment was preceded by musical commitment, Rouillan notes, 
as if the spaces occupied by youth cultural innovation required more than a temporal response. In the hands of Rouillan, rock's rebel pose became real. In May 1968, rock provided a soundtrack to a protest that further generated allusions to street fighting men and set about upturning the horrors of the twentieth century. Rouillan felt it and believed it; he did not just perform it.

Interestingly, the shift from music to militancy ensured Rouillan 'could no longer play music'. For others, of course, 1968 served as inspiration to revitalise popular music. With punk, the spirit of rebellion connected the subversive thrill of rock'n'roll to the seditious thrill of 1968's almost-revolution - or it did so for some anyway. As an aside, it may be worth pondering if the assault of Peter Brotzmann's Machine Gun or Anthony Braxton's This Time better captured the moment in the moment. Punk, after all, took time to gestate. Whatever, Rouillan recognised the feeling bound up in songs such as Them's 'Gloria': primal, raw, pushing to the edge of something. A soundtrack to chaos. The thrill of the fight ... or the fuck.

4 Yet, even as Rouillan lay down his guitar, he continued to find a soundtrack to the revolution in pop music. The Clash, and the DIY ethos associated with punk, are mentioned. This is interesting for several reasons. First, The Clash's signing to CBS was a contentious moment, a decision to engage on the inside rather than without. The band's experience - including the release of 'Remote Control' (1977) as a single without the group's consent - revealed the expected tension between art, protest and commerce, with the more cynical reader perhaps left wondering how far CBS consciously sought to cash-in via marketing The Clash's rebel-image ('turning rebellion into money'). Second, the experience of The Clash on CBS reaffirmed - for bands such as Crass and others of a less overtly anarchistic bent - the need to circumnavigate the music industry to better embody punk's oppositionism. Punk died, Mark Perry once said, on the day The Clash signed to CBS, an exaggerated remark that nevertheless allowed the innovator of Sniffin' Glue and ATV to seek more creative avenues under rather than over - ground. Third, and linked to this, punk's DIY was in some ways a response to The Clash (and the Sex Pistols') perceived co-option by the music industry. If the 'first wave' had been codified and commodified, then it was up to those who followed to forge a better and alternative path. Fourth, The Clash's relationship to politics was likewise contentious. In particular, the band's performance at the AntiNazi League carnival of 1978, whereat Joe Strummer wore a (mis-spelt) Brigade Rosse Tshirt brokered yet more debate. Already criticised for their trip to Belfast and the photos taken in front of the barricades, The Clash's evoking the armed struggle of Italian militants led to further condemnation, be it for fetishizing violence or dabbling in politics little understood. And yet, beyond the pose and the pretence, Rouillan's meeting with Strummer reaffirms the more general sense of The Clash as a band that mattered and meant well. They opened doors, literally, and the connection made between The Clash's smuggling fans into gigs and the 1970 Isle of Wight Festival confrontations is telling. The notion of punk being a 'year zero', a wholesale rejection of the hippie counterculture and a break from the past was always dubious, and Rouillan is surely right to recognise continuums. We may note, too, the double meaning of 'free music'; that is both costless and open to experimentation. Either way, boundaries are this way broken and crossed.

5 Indeed, the question of commodification looms large in Rouillan's interview and loomed large in punk's broader critique of both the music industry and society more 
generally. Be it Jamie Reid's artwork for the Sex Pistols or X-Ray Spex's dissection of consumerism, Gang of Four's agit-pop musical essays on the commodification of desire or Buzzcocks' breakdown of fiction romance, Rough Trade's co-op shop and label or Crass' anarchist communiqués, the 'fight against commodification' (as Rouillan puts it) was fought on many fronts. The Sex Pistols may be seen as a kamikaze mission into the heart of pop's spectacle. Following their impact, amidst the shrapnel and the mediagenerated horror, spaces opened up for previously untapped voices, sounds, labels, language and attitudes to find expression. Rouillan mentions British pubs, but there followed the arts centres, squats and collectives that likewise enabled bands to push the parameters of music. And as the 'expression of rage' transformed from anger to alienation, so the post-punk period from late 1977 fused with punk's DIY ethos to enable one of the most diverse and creative periods of music ever. The money was not the motive. Expression, originality, creativity, communication, agency, autonomy: these became the watchwords. Rouillan reveals a penchant for bands in small pubs or playing small gigs. There's a search for purity here: the moment before corruption.

Or ... the moment before the action. Once engaged in the armed struggle, so the music followed rather than preceded the moment of confrontation. Pink Floyd and classical music helped lower Rouillan's adrenalin. A soundtrack of urgency gave way to sounds of fluidity and contemplation. Maybe even silence. The industrial noise that Rouillan says the German Red Army Faction plotted to in the early 1980s might seem more attuned to the violence of the struggle: maybe the volume it was played at could affect the response of the listener? The harsh tones of Throbbing Gristle become soothing when played at minimal volume, more sound-bath than aural assault.

Industrial, obsessed about the media: about control processes and systems. Of all punk's associated cultures, industrial came closest to fetishizing political aesthetics and formulating music/sound as a weapon. When Rouillan talks of surveillance, it recalls the proto-sampling of Cabaret Voltaire and the fascination with fascism that informed the paranoid instincts of Throbbing Gristle's 'total war'. Here, of course, Rouillan was surveying those doing the surveillance. Punk, more generally, may be read as a dialogue with the media, a critique of distortions and double-standards, an alternative TV. Think of all those collages of newspaper headlines set against bland adverts and cropped photos from glossy magazines. Think of all those lyrics setting television as the new religion, or the impetus to do it rather than consume/absorb/observe it. But when Rouillan talks of intercepting communications, it reminds more of industrial's jamming of media signals and construction of alternative narratives. Herein, now the 1970s and 1980s are very much history, lay trace of collective memories that tell different stories and different possibilities. Resources of hope, Raymond Williams might say.

Certainly, amidst the scrambled (fake) news casts of the twenty-first century, such resources are important. As the interview notes, musics have a history and those histories are often bound to political struggles. The playing and the production, the language and the location, the music and the movement of the bodies. And it is those histories that help make music more than the 'soup' Rouillan compares much commercially-produced pop to. Context is all. Know your history. Never disentangle or atomize. In rock'n'roll he heard anger, frustration and the desire for change: love songs sung through gritted teeth. Where rock suggested a reconstitution of music, so the politics it served to soundtrack and conceive also sought to reinvent: to do different; to demand the impossible; to kiss the sky. In many ways, Rouillan's life sought to make 
tangible the world rock promised; to ensure the freedoms encapsulated in sound and feedback might shake off the chains of commerce and soiled tradition. The struggle against capital, reification, commodification and control - continues. There remains a world to win.

\section{ABSTRACTS}

This short commentary reflects on Luis Velasco-Pufleau's interview with Jean-Marc Rouillan. Picking up on the connections made between musical practice and political struggle, it locates Rouillan's life and thoughts in relation to punk and the subversive charge more general to rock'n'roll. By so doing, questions of freedom, action and commodification are considered, relating how cultural revolution may feed into political insurrection.

Ce court commentaire revient sur l'entretien que Luis Velasco-Pufleau a mené auprès de JeanMarc Rouillan. En reprenant les liens effectués entre pratique musicale et lutte politique, il contextualise la vie et la pensée de Rouillan en relation avec le punk et la charge subjective plus généralement propre au rock'n'roll. Pour ce faire, les questions de liberté, d'action et de marchandisation sont interrogées en perspective de la manière dont la révolution culturelle pourrait contribuer à l'insurrection politique.

\section{INDEX}

Mots-clés: révolution, rock'n'roll, punk, Action directe, musique, marchandisation

Keywords: revolution, rock'n'roll, punk, Action directe, music, commodification

\section{AUTHOR}

\section{MATTHEW WORLEY}

Matthew Worley is professor of modern history at the University of Reading and co-founder of the Subcultures Network. He has written widely on British labour and political history between the wars, though his more recent work has concentrated on the post-war relationship between youth culture and politics. Articles have been published in such journals as Contemporary British History, History Workshop, Popular Music and Twentieth Century British History. A monograph, No Future: Punk, Politics and British Youth Culture, 1976-84, was published by Cambridge University Press in 2017. As a co-founder of the Subcultures Network, he has also been involved in events, book series and publications such as Ripped, Torn \& Cut: Pop, Politics and Punk Fanzines from 1976 (Manchester University Press, 2018). 